\title{
Factors influencing plateletpheresis donations in Dr. Sardjito General Hospital, Yogyakarta, Indonesia
}

\author{
Aditya Wicaksana $^{1 *}$, Teguh Triyono ${ }^{2}$, Umi Intansari ${ }^{2}$ \\ ${ }^{1}$ Faculty of Medicine, Public Health, and Nursing, Universitas Gadjah Mada, Yogyakarta, \\ Indonesia, 'Department of Clinical Pathology, Faculty of Medicine, Public Health, and \\ Nursing, Universitas Gadjah Mada/Dr. Sardjito General Hospital, Yogyakarta, Indonesia
}

DOI: http://dx.doi.org/10.19106/JMedScie/005003201809

\section{ABSTRACT}

Despite its life saving potential, regrettably, blood transfusion has yet to be optimally applied in Indonesia. Funding difficulties and both public and professional lack of knowledge hinders its progress. More lives can be saved by using a safer, more proper, and specialized blood transfusion procedure. Plateletpheresis, one method to obtain platelet products, requires a different donation procedure than that of whole bloodderived platelet. High quality plateletpheresis product donation will positively impact the transfusion efficacy and platelet recovery of the recipient, improving patient's clinical state. This study analyzes factors from both the donor and donation procedure that influence the quality of plateletpheresis product. The study analyzes data of plateletpheresis donations from blood transfusion service and plateletpheresis transfusions from medical records at Dr. Sardjito General Hospital, Yogyakarta, Indonesia, within the period of August 2012 to January 2013 using cross sectional design. Forty-four plateletpheresis donations were obtained during the study. All donors were male with the following mean values; age 31.9 \pm 9.9 years, weight $70.2 \pm 10.2 \mathrm{~kg}$, body mass index (BMI) $24.7 \pm 3.2 \mathrm{~kg} / \mathrm{m} 2$, hematocrit $44 \pm 3.2 \%$, and procedure time $84.2 \pm 19.2 \mathrm{~min}$. The median value of platelet yield was $3.2 \times 10^{11}\left(2.1 \times 10^{11}-4 \times 10^{11}\right)$. The median value of pre-donation platelet count was $248.5 \times 10^{3} / \mu \mathrm{L}\left(204 \times 10^{3} / \mu \mathrm{L}-391 \times 10^{3} / \mu \mathrm{L}\right)$ and the mean value of product volume was 275 $\pm 22.9 \mathrm{~mL}$. The results showed that pre-donation platelet count $(r=0.329 ; p<0.05)$ and product volume $(r=0.661 ; p<0.05)$ positively correlated to the yield of platetetpheresis products. However, the yield of plateletpheresis products was not correlated to the posttransfusion platelet count $(r=0.327 ; p>0.05)$. In conclusion, pre-donation platelet count and product volume of plateletpheresis influence the yield of plateletpheresis. However, the yield is not correlated to the post-donation platelet count. Thus, other clinical factors should be considered.

\section{ABSTRAK}

Meskipun memiliki potensi besar dalam menyelamatkan manusia, transfusi darah belum diterapkan secara optimal karena terbatasnya pendanaan serta pengetahuan masyarakat dan tenaga medis di Indonesia. Lebih banyak jiwa dapat diselamatkan dengan menggunakan prosedur transfusi darah yang lebih aman, tepat, dan spesifik. Plateletferesis, salah satu metode untuk mendapatkan produk trombosit, membutuhkan prosedur donasi yang berbeda dibanding transfusi darah konvensional. Produk donasi plateletferesis yang berkualitas akan berdampak positif terhadap efikasi transfusi dan pemulihan trombosit penerima, sehingga dapat memperbaiki keadaan klinis pasien. Penelitian ini bertujuan untuk menganalisis faktor-faktor dari donor dan prosedur donasi yang mempengaruhi kualitas produk plateletferesis. Penelitian ini menggunakan rancangan potong lintang 
untuk menganalisis data donasi plateletferesis dari unit pelayanan transfusi darah (UPTD) dan data transfusi plateletferesis dari rekam medis di Rumah Sakit Umum Pusat Dr. Sardjito, Yogyakarta, Indonesia periode bulan Agustus 2012 hingga Januari 2013. Didapatkan 44 sampel penelitian. Semua donor adalah laki-laki dengan nilai rata-rata usia 31,9 \pm 9,9 tahun, berat badan 70,2 $\pm 10,2 \mathrm{~kg}$, indeks massa tubuh (IMT) $24,7 \pm 3,2 \mathrm{~kg} /$ $\mathrm{m} 2$, hematokrit $44 \pm 3,2 \%$, dan waktu prosedur $84,2 \pm 19,2$ menit. Nilai media hasil produk plateletferesis adalah $3,2 \times 10^{11}\left(2,1 \times 10^{11}-4 \times 10^{11}\right)$. Nilai median hitung platelet pra-donasi adalah $248,5 \times 10^{3} / \mu \mathrm{L}\left(204 \times 10^{3} / \mu \mathrm{L}-391 \times 10^{3} / \mu \mathrm{L}\right)$ dan nilai rerata volume produk adalah $275 \pm 22,9 \mathrm{~mL}$. Hasil penelitian menunjukkan bahwa jumlah platelet pra-donasi $(r=0,329$; $p<0,05)$ dan volume produk $(r=0,661 ; p<0,05)$ berkorelasi positif dengan hasil produk plateletferesis. Namun demikian, hasil produk plateletferesis tidak berkorelasi dengan hitung trombosit pasca transfusi $(r=0,327 ; p>0,05)$. Dapat disimpulkan, jumlah platelet pra-donasi dan volume produk plateletferesis mempengaruhi hasil produk plateletferesis. Namun, hasil produk plateletferesis tidak berkorelasi dengan hitung platelet pasca-donasi. Faktor klinik lainnya harus dipertimbangkan dalam plateletferesis.

Keywords: platelet - plateletpheresis - pre-donation - post-donation - platelet countproduct

\section{INTRODUCTION}

Millions of people all over the world are saved by blood transfusions annually. ${ }^{1}$ To obtain an optimal results in blood transfussion, it is important to provide a safe method of blood transfusion in accordance to the standard and comprehensive workflow to obtain an optimal result in blood transfusion, thus increasing the quality of care. ${ }^{1,2}$ Recently, blood transfusions use specific blood components that meet certain requirements. For example, the need for red blood cells, granulocytes, platelets and blood plasma that contain specific proteins and clotting factors. To reduce the adverse effects of transfusions, a clear guideline for the transfusion of specific blood components is needed. ${ }^{3}$ One blood component that is commonly used in transfusions is platelets, through a procedure known as plateletpheresis.

Plateletpheresis is a blood donation process of removing whole blood from the donor, separating only the platelets, and then returning the remaining blood components (erythrocytes, leucocytes and blood plasma) to the donor. Patients requiring platelet transfusions can receive platelet products through platelet concentrates or a plateletpheresis. Over the years, plateletpheresis has been considered superior to platelet concentrates. ${ }^{4,5}$ One study reveals plateletpheresis components are considered to be fresher than platelet concentrates, since plateletpheresis components are specially collected for specific patients. ${ }^{3}$ Another study shows plateletpheresis provide better platelet increments, and cause less alloimmunization. ${ }^{5}$ The major advantages are also that there is a reduced donor exposure and a therapeutic dose can be collected from a single donor with special characteristics, such as HLA-matched, PIA1 negative, or IgA-deficient. ${ }^{6}$ Data from the American Red Cross also showed a lower risk of transfusion reaction due to bacterial contamination from plateletpheresis rather than to platelet concentrates. ${ }^{7,8}$

Although gradually increasing, plateletpheresis is still quite new in Indonesia and rarely performed. This pattern is caused by several factors; the aphaeresis machine is quite expensive, and there are limited aphaeresis donors due to the predonation terms and conditions that have to be fulfilled by the donors. This fact needs to be attended to, as it is expected that 
plateletpheresis can provide optimal results in every donation in terms of efficiency and efficacy. The plateletpheresis product quality is influenced by two aspects: the donor itself and the donation procedure. ${ }^{4}$ To the author's knowledge, unfortunately, there have been no studies done in Indonesia that analyze factors influencing the plateletpheresis product quality. A high quality of plateletpheresis product donation will positively impact the transfusion efficacy and platelet recovery of the recipient, improving his or her clinical state and outcome. It is thus essential to further elaborate the profile of plateletpheresis donation.

\section{MATERIALS AND METHODS}

\section{Design of the study}

This cross sectional study was conducted at the blood transfusion service unit (Unit Pelayanan Transfusi Darah/UPTD) and the Medical Records Department (Instalasi Rekam Medis/IRM) Dr. Sardjito General Hospital, Yogyakarta. The samples used in this study were 44 data sets of plateletpheresis donations within the period August 2012 to January 2013. The study began with collecting data of plateletpheresis donations in UPTD within the period of August 2012 to January 2013.

\section{Data collection}

We assessed data from the donors characteristics including: age, gender, body weight, BMI (body mass index), hematology profiles (hematocrit and predonation platelet count); as well as aspects of the donation procedure, which include the duration of donation procedure and volume of plateletpheresis products; and from the aspects of the product which include the yield of plateletpheresis. After that, we collected data of recipients who received transfusions by donors that have been recorded previously and within the timeframe specified in the IRM. The data of recipients that were taken in the medical record specified the increase in the number of platelets after transfusion (platelet increment) to assess the efficacy of the transfusion.

\section{Statistical analysis}

The collected data were then analyzed and compared to determine whether there was a relationship or correlation between the variables using the Statistical Package for Social Science (SPSS). The Spearman's rho correlation test was used to evaluate the correlation between pre-donation platelet count and the yield of plateletpheresis, the age of the donor and the yield of plateletpheresis, weight of the donor and the yield of plateletpheresis, hematocrit value and the yield of plateletpheresis. The one-way ANOVA was used to evaluate the differences between the means of the three age groups. A $p$ value $<0.05$ was considered to be significant.

\section{RESULTS}

Forty-four plateletpheresis donations were obtained during the study. All donors/ subjects were male. The age range of donors ranged from 18 to 55 years with a mean age of $31.95 \pm 9.92$ years (TABLE 1 ).

TABLE1. The characteristic of donors by age

\begin{tabular}{lcc}
\hline Age group (years) & Number of subjects & Percentage (\%) \\
\hline$<30$ & 18 & 40.9 \\
$30-40$ & 17 & 38.6 \\
$>40$ & 9 & 20.5 \\
\hline Total & 44 & 100 \\
\hline
\end{tabular}

The mean values of donors' basic characteristics were as follows weight was $70.2 \pm 10.2 \mathrm{~kg}$, BMI was $24.7 \pm 3.2 \mathrm{~kg} / \mathrm{m}^{2}$, and hematocrit was $44.05 \pm 3.29 \%$ (TABLE 2).

TABLE 2. The basic characteristics of donors

\begin{tabular}{lc}
\hline \multicolumn{1}{c}{ Characteristic } & Mean $\pm \mathrm{SD}$ \\
\hline Age (years) & $31.95 \pm 9.92$ \\
Weight $(\mathrm{kg})$ & $70.2 \pm 10.24$ \\
BMI $\left(\mathrm{kg} / \mathrm{m}^{2}\right)$ & $24.7 \pm 3.2$ \\
Hematocrit $(\%)$ & $44.05 \pm 3.29$ \\
\hline \hline
\end{tabular}


The median value of the yield of plateletpheresis was $3.2 \times 10^{11}$, with a maximum value of $4 \times 10^{11}$, and the minimum value of
$2.19 \times 10^{11}$. The distribution of the median value of the yield of plateletpheresis in each donor is shown in FIGURE 1.

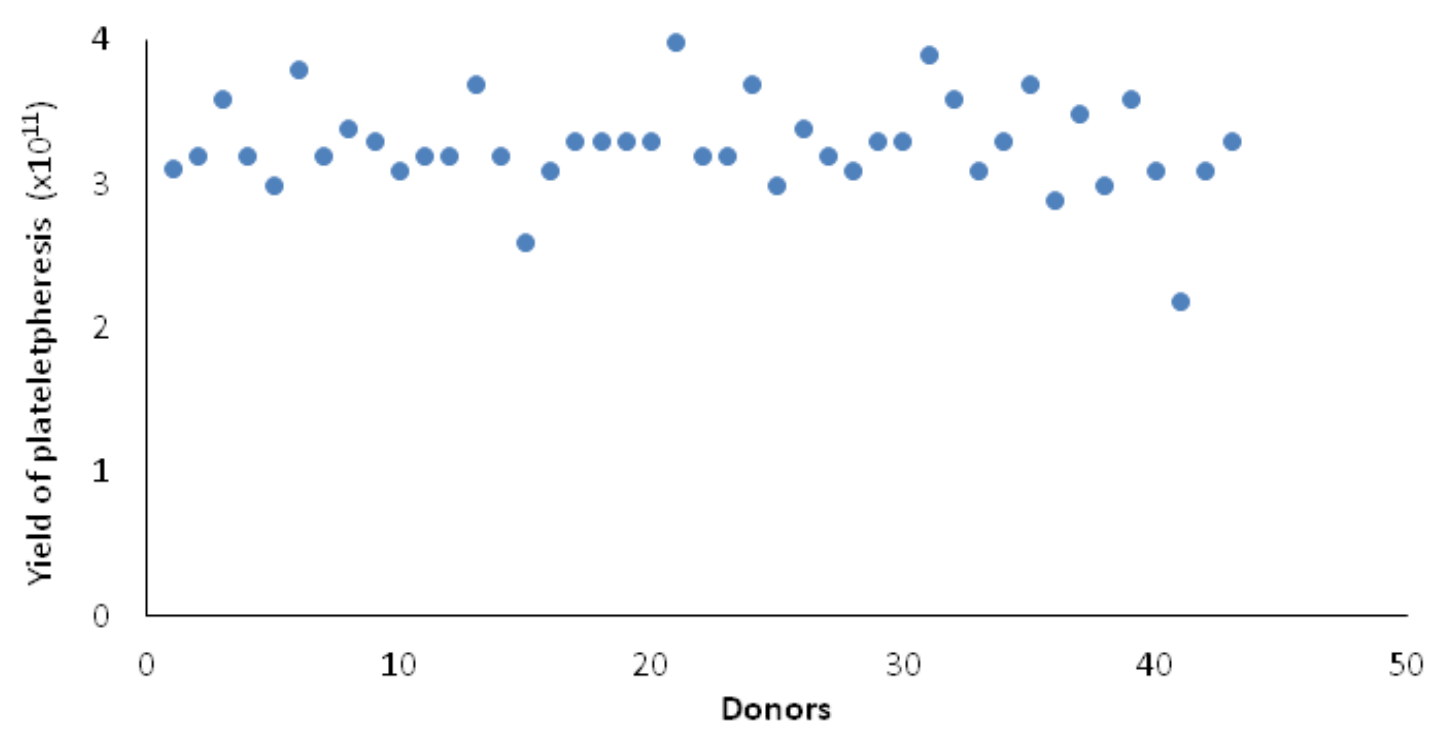

FIGURE 1. Distribution of the median value of the yield of plateletpheresis in donors

The median value of pre-donation platelet count in donors was $248.5 \times 10^{3 /}$ $\mu \mathrm{L}$ with the maximum value of $391 \times 10^{3} /$ $\mu \mathrm{L}$, and minimum value of $204 \times 10^{3} / \mu \mathrm{L}$.
The distribution of the median value of the pre-donation platelet count in each donor is shown in FIGURE 2.

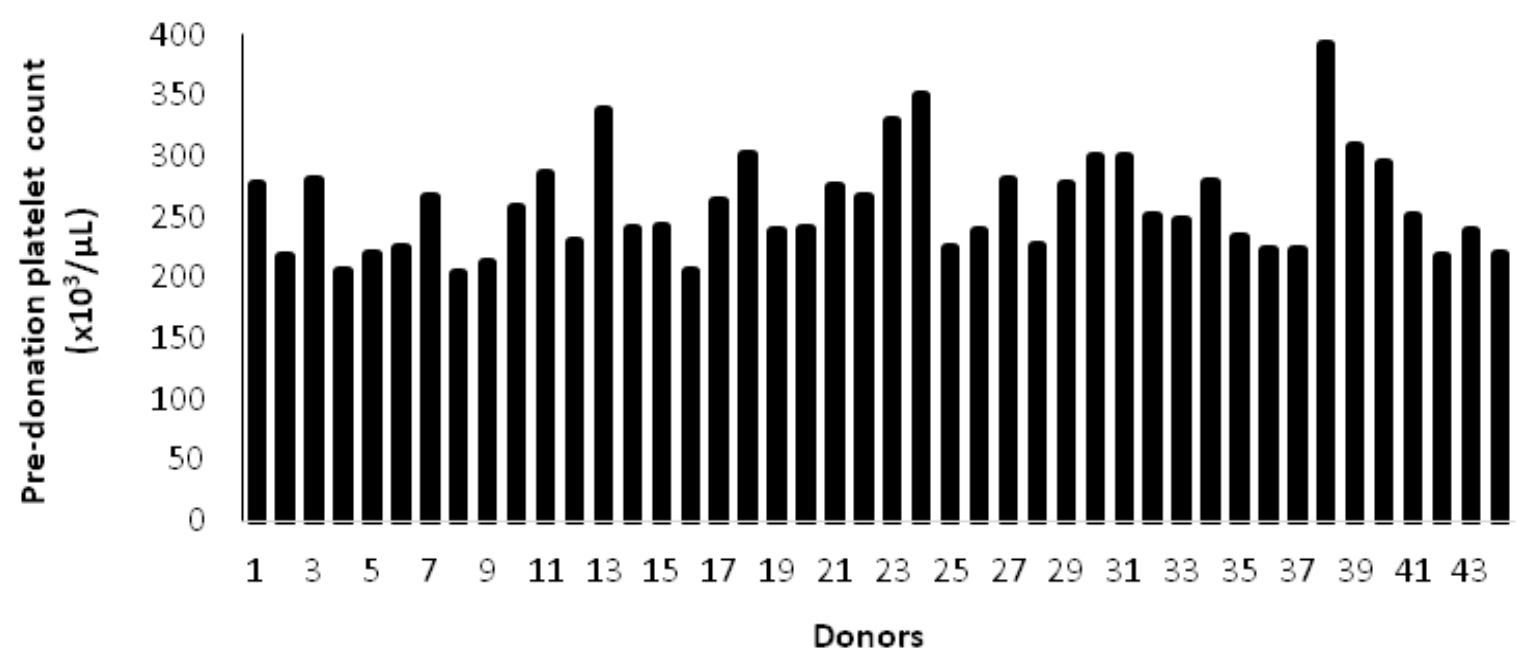

FIGURE 2. The distribution of the median value of the pre-donation platelet counts in donors 
From the result of Spearman's rho correlation test, it was found that the correlation between pre-donation platelet count and the yield of plateletpheresis was statistically significant $(p<0.05)$. The value of Spearman's rho coefficient correlation of 0.329 indicated that the direction of the correlation was moderately positive. Therefore, the pre-donation platelet count was positively correlated with the yield of plateletpheresis and was statistically significant.The mean value of plateletpheresis in the age group of less than 30 years was $3.35 \pm 0.26 \times 10^{11}$, while in the age group of 30 to 40 years, the mean value was $3.17 \pm 0.39 \times 10^{11}$, and in the age group of above 40 years, the mean value was 3.32 $\pm 0.23 \times 10^{11}$ (TABLE 3 ).

TABLE 3. Distribution of the yield of plateletpheresis based on age group

\begin{tabular}{lcc}
\hline Age (years) & $\begin{array}{c}\text { Number of } \\
\text { Subjects }\end{array}$ & $\begin{array}{c}\text { Mean } \pm \text { SD } \\
\left(\times 10^{11}\right)\end{array}$ \\
\hline$<30$ & 18 & $3.35 \pm 0.26$ \\
$30-40$ & 17 & $3.17 \pm 0.39$ \\
$>40$ & 19 & $3.32 \pm 0.23$ \\
\hline
\end{tabular}

The result of Spearman's rho correlation test showed that the correlation between the age of the donor and the yield of plateletpheresis was not significant $(p>0.05)$. The value of Spearman's rho coefficient correlation of -0.137 indicated that the direction of the correlation was negative. Thus, it can be concluded that there was no correlation between age of the donor and the yield of plateletpheresis. We also performed oneway ANOVA correlation test to determine whether there were any statistically significant differences between the means of the three age groups. It was found that there was no difference between donor age groups and the yield of plateletpheresis compared to one another $(\mathrm{p}=0.238)$.

Spearman's correlation test results showed that the correlation between weight of the donor and the yield of plateletpheresis was not significant $(p>0.05)$. The value of Spearman's rho coefficient correlation test of 0.033 indicated that the direction of the correlation was positive. Thus, we concluded that there was no correlation between weight and the yield of plateletpheresis.Similar correlation tests were performed on the Body Mass Index (BMI) variable. It was found that the correlation between BMI of the donors and the yield of plateletpheresis was not significant $(p>0.05)$. The coefficient correlation value of 0.027 indicated that the direction of the correlation was positive. Thus, we concluded that, there was no correlation between BMI and yield of plateletpheresis.

In the hematocrit variable, there was no significant correlation $(p>0.05)$ in the result of Spearman's rho. The value Spearman's rho coefficient correlation test of -0.156 indicated that the direction of the correlation was negative. Thus, we concluded that there was no correlation between the hematocrit value and the yield of plateletpheresis. From the aspect of the donation procedure, we obtained the mean value of the product volume of platetelpheresis was $275 \pm 2.9$ $\mathrm{mL}$ and the mean value of the duration of plateletpheresis was $84.2 \pm 19.2$ minutes. The distribution of the mean value of the product volume in each donor is shown in FIGURE 3, and the distribution of the mean value of the duration of plateletpheresison each donor is shown in FIGURE 4. 


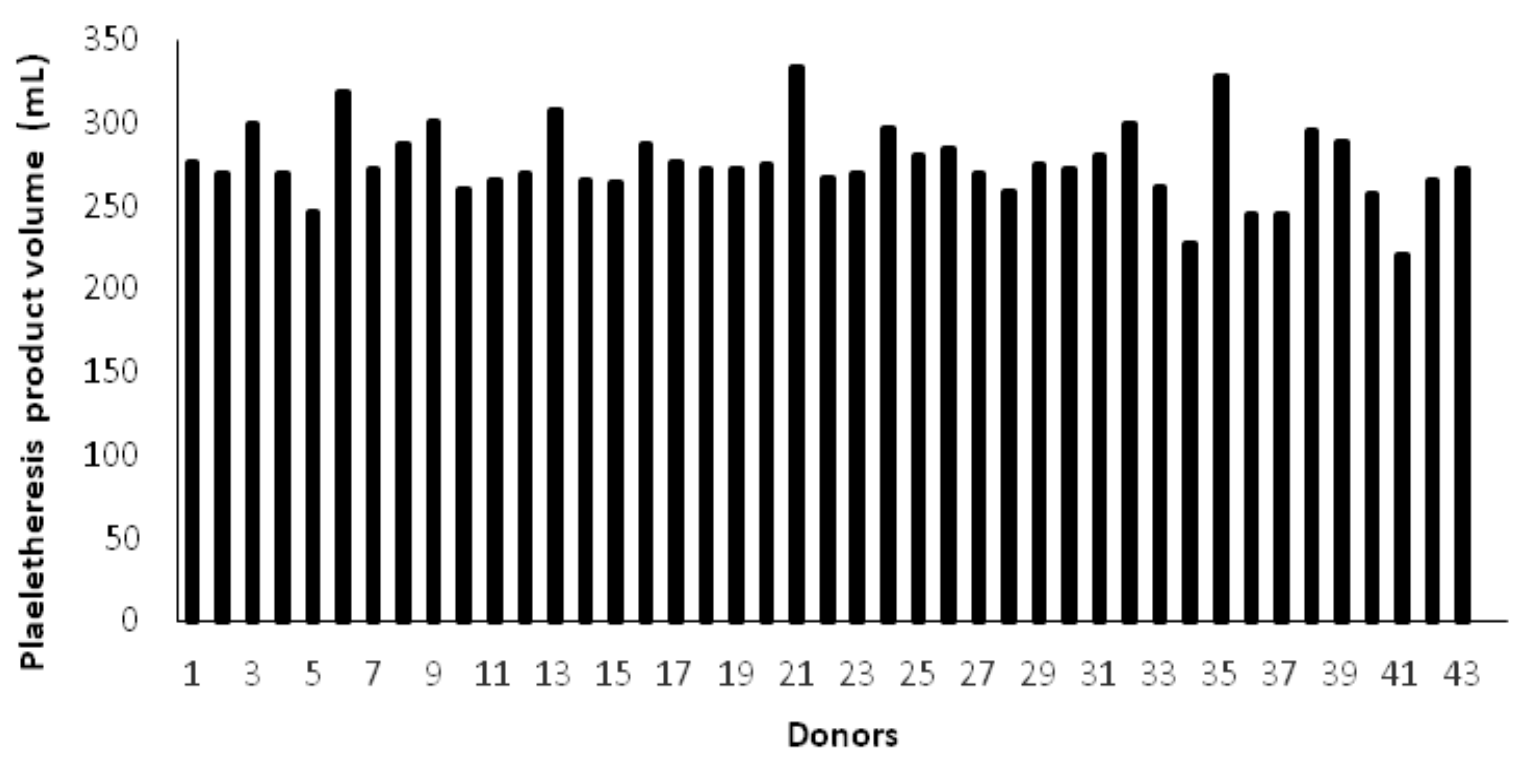

FIGURE 3. Distribution of the mean value of the product volume of plateletpheresis in donors

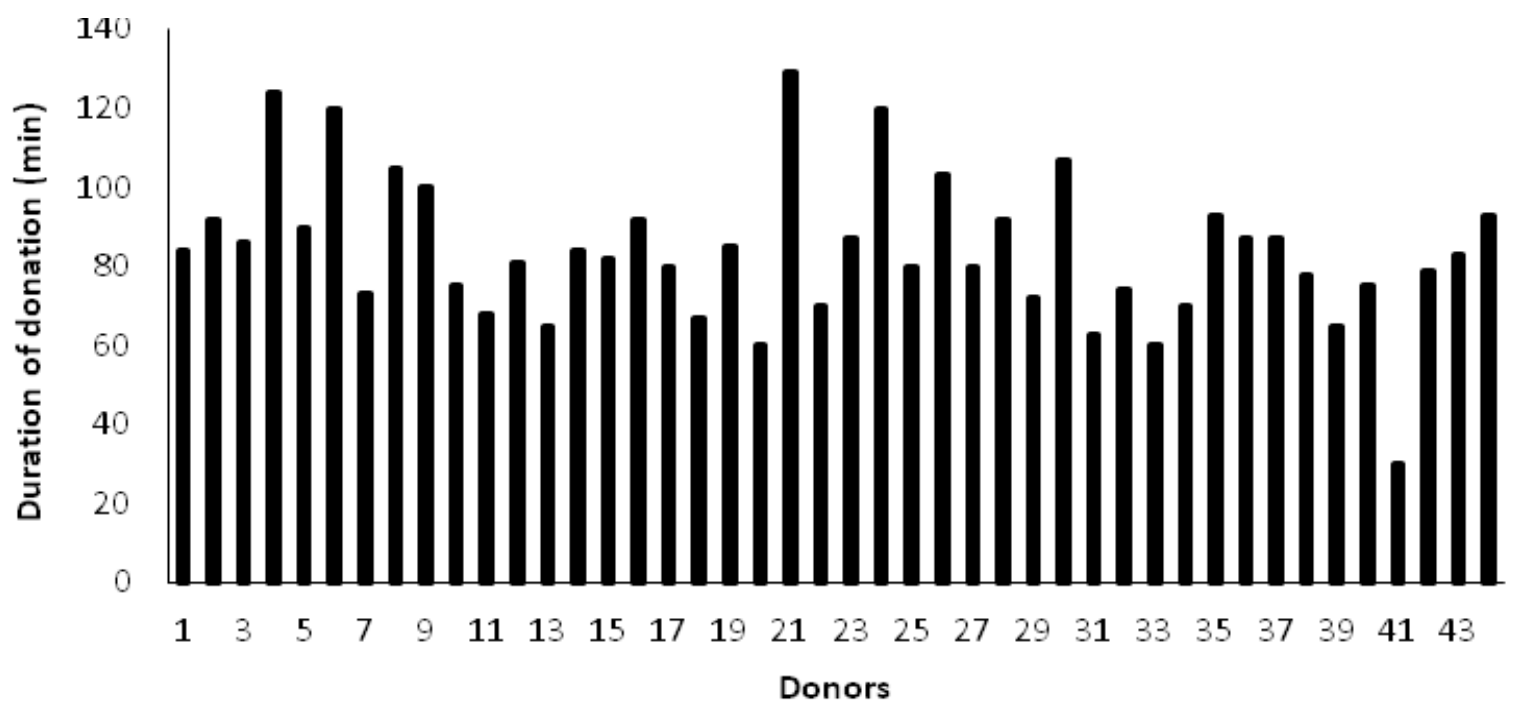

FIGURE 4. Distribution of the mean value of the duration of plateletpheresis in donors

The result of Spearman's rho correlation test showed that the correlation between the product volume of plateletpheresis and the pre-donation plateletcount was not significant $(p>0.05)$. The value of Spearman's rho coefficient correlation test of 0.211 indicated that the direction of the correlation was positive. Thus, we concluded that there was no correlation between the product volume of plateletpheresis and the pre-donation platelet count. The next result of Spearman's rho showed that the correlation between the product volume of plateletpheresis and the yield of plateletpheresis was significant $(p<0.05)$. The value of Spearman's rho coefficient correlation test of 0.661 indicated the moderately positive correlation. Thus, we concluded that the product volume of plateletpheresis was moderately positively correlated with the yield of plateletpheresis and was statistically significant.

From the donation procedure variable, 
the results of Spearman's rho correlation test found that the correlation between the duration of plateletpheresis and the yield of plateletpheresis was not significant $(\mathrm{p}>0.05)$. The value of Spearman's rho coefficient correlation test of 0.224 indicated that the direction of the correlation was positive. Thus, we concluded there was no correlation between the duration of the plateletpheresis and the yield of plateletpheresis.We examined the recipient data in the medical records that contain the increase of posttransfusion platelet count. In the medical records, there were only 27 recipients who received transfusions from the donors. This limited number then affected the reduced number of samples when we were analyzing the correlation between the increased yield of plateletpheresis and the post-transfusion platelet count.

With these limitations, we analyzed the correlation between the yield of plateletpheresis of the donor and the increased number of platelets after transfusion (platelet increment) of the recipient. Normality test showed that the distribution of the yield of plateletpheresis was not normal despite performing data transformation. Thus, we performed Spearman's rho correlation test. From the result of Spearman's rho correlation test, we found that the correlation between the yield of plateletpheresis and the increase number of platelet after transfusion (platelet increment) of the recipient was not significant $(p>0.05)$. The value of Spearman's rho coefficient correlation test of 0.327 indicated that the correlation was positive. Thus, it can be concluded that there was no correlation between the yield of plateletpheresis of the donor and the increase number of platelets after transfusion (platelet increment) of the recipient.

\section{DISCUSSION}

Our study shows similar findings with previous studies, that the pre-donation platelet count is positively and statistically significantly correlated with the yield of plateletpheresis (TABLE 4). Predonation platelet count is the main factor that is believed to influence the yield of plateletpheresis. The higher the number of pre-donation platelet count, the higher the yield of plateletpheresis. ${ }^{6}$

TABLE 4. Comparison with other studies

\begin{tabular}{lllllllll}
\hline Correlation & $\begin{array}{l}\text { Goodnough } \\
\text { et al. }\end{array}$ & Rajendra et al. & Das et al & $\begin{array}{l}\text { Guerero- } \\
\text { Rivera et al. } \\
\text { grup 1 }\end{array}$ & $\begin{array}{l}\text { Guerero- } \\
\text { Rivera et } \\
\text { al. grup 2 }\end{array}$ & Enein et al. & Patel et al. & This study \\
\hline Pre-donation PC & $\begin{array}{l}\text { Direct cor- } \\
\text { relation }\end{array}$ & $0.506(<0.05)$ & $\begin{array}{l}0.51 \\
(<0.05)\end{array}$ & 0.554 & 0.758 & 0.512 & $0.302(<0.05)$ & $0.329(<0.05)$ \\
Pre-donation Hb & - & $-0.1(>0.05)$ & $\begin{array}{l}0.05 \\
(>0.05)\end{array}$ & $\begin{array}{l}\text { Inverse } \\
\text { correlation }\end{array}$ & $\begin{array}{l}\text { Inverse } \\
\text { correlation }\end{array}$ & 0.306 & $-0.001(>0.05)$ & - \\
Pre-donation Hct & - & - & - & - & - & - & $-0.018(>0.05)$ & -0.213 \\
Donor's weight & - & 0.18 & - & - & - & - & $0.023(>0.05)$ & $0.033(>0.05)$ \\
Duration & - & - & - & - & - & - & $-0.047(>0.05)$ & $0.224(>0.05)$ \\
Volume & - & - & - & - & - & - & $0.158(<0.05)$ & $0.661(<0.05)$ \\
\hline
\end{tabular}


Several studies mentioned that age was a factor that influences the yield of plateletpheresis. One study recently concluded that age was negatively and significantly correlated with the yield of plateletpheresis - the older the donor, the lower the yield of plateletpheresis. ${ }^{9}$ However, in our study, there is no correlation between age and yield of plateletpheresis (TABLE 4.).Weight and BMI are several factors from the donor that are believed can influence the yield of plateletpheresis. ${ }^{10}$ Body mass index is an indicator of the amount of tissue mass (muscle, fat, and bone) in an individual. A study showed that BMI has a positive correlation with the yield of plateletpheresis. ${ }^{9}$ However, another study found that weight is not correlated with the yield of plateletpheresis. ${ }^{10}$ The BMI reflects weight and body mass in line with the blood volume. Someone with greater blood volume has a tendency to produce higher platelet count. ${ }^{11}$ However, in our study, body weight and BMI are not correlated with the yield of plateletpheresis (TABLE 4).

Another factor of the donor that influences the yield of plateletpheresis is the hematocrit value. Hematocrit indicates the proportion or percentage of erythrocyte components contained in blood components as a whole - the higher the hematocrit value, the smaller the other blood components, including platelets. One study revealed that the hematocrit value is negatively and statistically significant correlated with the efficiency of plateletpheresis collection. ${ }^{12}$ Other studies find no correlation between pre-donation hematocrit value with the yield of plateletpheresis. ${ }^{5}$ Similarly, in our study, there is no correlation between the hematocrit value and the yield of plateletpheresis. The guidelines issued by the American association of blood banks (AABB) stated that the pre-donation hematocrit value of the donor has to achieve at least $38 \%$, and in our study, the mean hematocrit value was $44 \pm$ $3.29 \%$.

All subjects in our study were male. Thus, we could not analyze the correlation between gender and the yield of plateletpheresis. One study found that women produced a higher yield of plateletpheresis than men. ${ }^{10}$ This result may be due to the prevalence of iron deficiency in women, leading to low hemoglobin levels. Low levels of hemoglobin, then, as mentioned above, result in an increase in the number of platelets, which then increases the yield of yield plateletpheresis. ${ }^{6}$ Again, from the donor aspect, one interesting study found that donors with low hemoglobin level would produce a high yield of plateletpheresis and vice versa. That result was because low hemoglobin level provides a high level of pre-donation plasma volume that produces a high yield of plateletpheresis. ${ }^{8}$ However, another study found that hemoglobin level had no correlation with the yield of plateletpheresis. ${ }^{14}$ This research was unable to assess the correlation of the hemoglobin level with the yield of plateletpheresis because there was no history or information regarding the pre-donation hemoglobin level of the donors.

From the aspect of plateletpheresis procedure, it is mentioned that the product volume of plateletpheresis is correlated to the yield of plateletpheresis. Based on FDA guidelines, the volume of plateletpheresis' products (excluding anti-coagulant) should not exceed $500 \mathrm{~mL}$ (or $600 \mathrm{~mL}$ of the donor with a body weight greater than or equal to $80 \mathrm{~kg}$ ). One study revealed that the product volume of plateletpheresis correlated positively and was statistically significant to the yield of plateletpheresis showing that the higher the product volume of plateletpheresis, the higher the yield of plateletpheresis. ${ }^{9}$ The study also found that the product volume of plateletpheresis is one of the main factors of the procedural aspects that influence the yield of plateletpheresis. Similarly, in our study, the product volume of plateletpheresis has a positive and statistically significant correlation with the yield of plateletpheresis. Thus, our study is in line with the existing studies.

In this study, we also analyzed 
the correlation between pre-donation platelet count and the product volume of plateletpheresis. There is no correlation between the number of pre-donation platelet count and the product volume of plateletpheresis. However, few studies analyzed the pre-donation platelet count with the yield of plateletpheresis, instead of the product volume of plateletpheresis. Another aspect of the procedure that is considered in a few studies to have a correlation with the yield of plateletpheresis is the duration of the donation procedure (plateletpheresis). One study mentioned that a high yield of plateletpheresis can be obtained from a high pre-donation platelet count and less duration of plateletpheresis. ${ }^{12}$ In this study, we find no correlation between the duration of plateletpheresis and the yield of plateletpheresis. It is explained in several studies that the duration of the procedure varies from 20 to $120 \mathrm{~min}$, depending on the product being donated, as well as the number of cells, the size of the donor, vascular access, technical factors, and other limitations on the procedure. ${ }^{14,15}$

In our research, there is no correlation between the increase number of posttransfusion platelet count (platelet increment) and the yield of plateletpheresis. This result might be due to a limitation in our study, which used a variable of Absolute Count Increment (ACI), instead of Corrected Count Increment (CCI). ACI, in this case, is the increase in the number of platelets after transfusion. Some studies show a positive correlation between the yield of plateletpheresis and the efficacy of transfusion using CCI variable. Limitations of this study might also include the unavailability of height and weight data of the recipient in some medical records, which is required for the calculation of the body surface area and CCI.

\section{CONCLUSION}

It can be concluded that the predonation platelet count and the product volume of plateletpheresis influence the yield of plateletpheresis. Optimization of the yield of plateletpheresis, which is influenced by pre-donation platelet count and the production volume of plateletpheresis, is an emerging issue in blood transfusion services. However, the yield of plateletpheresis itself is not correlated with the number of post-transfusion platelet count. Thus, other clinical factors must be considered. It is necessary to consider other indicators such as CCI, to assess the efficacy of the transfusion. Therefore, further research with more samples should be conducted.

\section{ACKNOWLEDGEMENTS}

We would like to thank all the parties who involve in this study, and also Director of Dr. Sardjito General Hospital, Yogyakarta for the permission to perform this study.

\section{REFERENCES}

1. Cancer.org. Blood transfusions for people with cancer. [serial online] [citet Apr 10, 2018]. Available at: https:// www.cancer.org/treatment/treatmentsand-side-effects/treatment-types/bloodtransfusion-and-donation/what-aretransfusions.html.

2. Rebulla P, Stroncek DF. Platelet transfusion. Lancet 2007; 370(9585):427-38. https://doi.org/10.1016/S0140-6736(07)61198-2

3. Anonym. Consesus conference: platelet transfusion therapy. JAMA 1987;257(13):1777-80. http://dx.doi.org/10.1001/jma.1987.03390130095036

4. Taft EG.Application history. In: McLeod BC, Szczepiorkowski ZM, Weinstein R, Winters JL editors. Apheresis: principles and practice, $3^{\text {rd }}$ ed. Maryland: AABB Press 2010; 27-44.

5. Trial to Reduce Alloimmunization to Platelets Study Group. Leukocyte 
reeduction and ultraviolet $\mathrm{B}$ irradiation of platelets to prevent alloimmunization andrefractoriness to platelettransfusions. N Engl J Med 1997;337(26):1861-9. http://dx.doi.org/10.1056NEJM199712253372601

6. Cable GR \& Edwards LR. The use of platelet concentrates versus plateletpheresis-the donor perspective. Transfusion 2001; 41(6):727-9. http://dx.doi.org/10.1046j.1537-2995.2001.41060727x

7. Shastry S \& Chaudhary R. Clinical factors influencing corrected count increment. Transfusion and apheresis science. 47(3):327-30.

http://dx.doi.org/10.1016/j.transci.2012.04.006

8. Patel J, Nishal A, Pandya A, Patel P, Wadhwani S. Factors influencing yield of platelet aphaeresis using continuous flow cell separator. Int J Med Sci Public Health 2013; 2(3):309-12.

http://dx.doi.org/10.5455/ijmsph.2013.2.323-326

9. Arun R, Yashovardhan A, Deepthi K, Suresh B, Babu KV, Jothibai DS. Donor demographic and laboratory predictors of single donor platelet yield. J Clin Sci Res 2013; 211-5.

10. Buchholz DH, Squires JE, Herman JH, Ng AT, Anderson JK, Hedberg SL. Plateletpheresis in 90-to 110-pound donors using the CS-3000 blood cell separator. Transfusion 1997; 37(7):7158. hthp//dxdoiolor/10.1046j.1537-2995.199737797369447x

11. Slichter SJ, Davis K, Enright H, Braine $\mathrm{H}$, Gernsheimer T, Kao KJ, et al. Factors affecting post transfusion platelet increments, platelet refractoriness, and platelet transfusion intervals in thrombocytopenic patients. Blood 2005; 105(10):4106-14.

http://dx.doi.org/10.1182/blood-2003-08-2724

12. Landzo E, Sofo-Hafizovic A, CetkovicBasic V. Initial values ofdonor hematocrit and efficiency of plateletpheresis. Acta Inform Med 2013; 21(2):116-9.

http://dx.doi.org/10.5455/aim.2013.21.116-119

13. Lasky LC, LinA, Kahn RA, McCullough J. Donor platelet response and product quality assurance in plateletpheresis. Transfusion1981; 21(3):247-60. htip://xdoi.org/10.1046j.1537-2995.198121381201794x

14. Das SS, Chaudhary RK, Shukla JS. Factors influencing yield of plateletpheresis using intermittent flow cell separator. Clin Lab Haematol 2005; 27(5):316-9.

http://dx.doi.org/10.1111/j.1365-2257.2005.00714.x

15. Murphy S, Vassallo RR. Aphaeresis platelet collection, storage, quality assessment, and clinical use. In: McLeod BC, Szczepiorkowski ZM, Weinstein R, Winters JL eds. Aphaeresis: principles and practice, $3^{\text {rd }}$ ed. Maryland: $A A B B$ Press 2010; 141-65. 